Laslo Šereš ${ }^{1}$

Nemanja Lukić ${ }^{2}$

Vesna Rodić Lukić ${ }^{3}$
JEL: 123

DOI: 10.5937/industrija47-18202

UDC:316.644:[378:006.015.5(497.11) 378.147:33]:159.9.019.4

Original Scientific Paper

\title{
Analysis of the Relationship Between the Quality of Academic Service and the Behavioural Intentions of University Students
}

\author{
Article history: \\ Received: 10 March 2019 \\ Sent for revision: 14 March 2019 \\ Received in revised form: 17 June 2019 \\ Accepted: 17 June 2019 \\ Available online: 4 July 2019
}

\begin{abstract}
This paper examines whether the behavioural intentions of students are driven by the quality of services provided by faculty management, academic and administrative staff. The sample included 517 students from the University of Novi Sad, Serbia. In order to investigate the relationship between academic service quality and behavioural intentions, hierarchical multiple regression analysis (HMRA) was conducted. Results of HMRA have shown that approachability and support of academic staff and support of faculty management have both statistically significant relation to behavioural intentions of students. The findings of this research study suggest that the improvement of the academic service quality might foster students' behavioural intentions.
\end{abstract}

Keywords: Higher Education, Service Quality, Behavioural intentions.

\section{Analiza odnosa kvaliteta usluga visokog obrazovanja i bihejvioralnih namera univerzitetskih studenata}

Apstrakt: U ovom radu se istražuje da li su namere studenta vođene kvalitetom servisa pruženog kako od menadžmenta fakulteta, tako $i$ od osoblja koje pruža nastavne i administrativne usluge studentima. Uzorak istraživanja obuhvata 517 studenata Univerziteta u Novom Sadu. U cilju

\footnotetext{
${ }^{1}$ University of Novi Sad, Faculty of Economics Subotica

2 University of Novi Sad, Faculty of Education in Sombor,nemanja.lukic@pef.uns.ac.rs

${ }^{3}$ University of Novi Sad, Faculty of Education in Sombor
} 
Šereš L. et al.: Analysis of the Relationship Between the Quality of Academic Service..

ispitivanja postojanja statistički značajne povezanosti između kvaliteta usluga visokog obrazovanja $i$ bihejvioralnih namera studenata, korišćena je hijerarhijska višestruka regresiona analiza. Rezultati analize su pokazali da dostupnost i podrška nastavnog osoblja, kao i podrška menadžmenta fakulteta imaju statistički značajnu povezanost sa bihejvioralnim namerama studenata. Rezultati ove studije ukazuju da se unapređenje kvaliteta usluge na univerzitetu pozitivno odražava na namere ponašanja studenata.

Ključne reči: Visoko obrazovanju, kvalitet usluga, namere ponašanja

\section{Introduction}

Unlike the majority of studies in which students' intentions have been explored mostly from the aspect of their persistence and retention, a small number of papers deals with the examination of behavioural intentions of students as key users of educational services. Some authors examined behavioural intentions (BI) of students relying on development of loyalty as a key aspect of the service quality development (Dado, Petrovicova, Cusovic, \& Rajic, 2012; Danjuma \& Rasli, 2012;), and student satisfaction (Endres et al., 2009; Liaw, 2008; Park, 2009). On the other hand, Watjatrakul (2014) states that improving the quality of services rendered by introducing student-as-customer approach, leads to a positive attitude regarding the intentions of students on the admissibility of such a concept, reflecting positively to their satisfaction and the decision to continue their studies.

The fundamental problem in practice is that the most of public HEls are mainly recognised as social institutions, especially in developing countries, and in their traditionally-oriented management policies they do not recognise students as key consumers of educational services. As a consequence, the importance of the quality of educational services is not sufficiently recognised, especially not in the context of their impact on students' BI.

This study is focused on the phenomenon of students' $\mathrm{BI}$, and it investigates whether the $\mathrm{BI}$ of students is driven by the quality of services provided by faculty management, academic and administrative staff. The main purpose of this paper is the investigation of the impact of higher education service quality on student's behavioural intentions. Due to the preceding, faculty management needs to consider all of the possible determinants and components of service quality and attempt to determine which of those will have the strongest impact on student intentions.

According to those above, the following research question was imposed:

$\mathbf{R Q}$ : Which service quality manifest variables are predictors of students behavioural intentions?

The research question should contribute to a deeper understanding of the 
Šereš L. et al.: Analysis of the Relationship Between the Quality of Academic Service..

connection between the identified manifest variables and students' $\mathrm{BI}$.

\section{Literature overview}

\subsection{Service quality}

In order to define academic service quality, several definitions from the profit sector could be modified. Accordingly, it can be defined as the difference between the student's expectation related to the services and their perceptions of the service delivered (O'Neill \& Palmer, 2004; Sumaedi, Bakti, \& Metasari, 2011). Academic and administrative staff have a significant impact on the student's service quality perceptions. Results of previously conducted studies (Oldfield \& Baron, 2000; Voss, Gruber, \& Szmigin, 2007) emphasised the importance of the quality of personal contacts with academic staff as well the importance of the behaviour and attitudes of professors.

Service quality is mostly seen as a multidimensional concept according to different authors (Grönroos, 1984, Faganel, 2010; Veljković, 2009). When the SERVQUAL approach was developed, relying on the GEP quality model, these dimensions were reduced to five basic ones. These five dimensions of service quality within the SERVQUAL model, measured through 22 statements, are namely: reliability, responsibility, assurance, empathy and tangible dimension (Faganel, 2010; Rodić, 2016). On the other hand, Grönroos (1984) created a model of perceived service quality, which account in only two dimensions: technical (what the consumer receives) and a functional dimension (in what way). Following the modelling of the technical and functional dimensions of quality, Rapert et al. (2004, mentioned at Letcher \& Neves, 2010) proposed two concepts of quality in higher education namely: process quality attributes and functional or outcome quality attributes.

\subsection{Service quality and student-faculty relationship}

Several authors (Arnett, German, \& Hunt, 2003; Helen \& Ho, 2011; HennigThurau, Langer, \& Hansen, 2001; Jurkowitsch, Vignali, \& Kaufmann, 2006; Rashid \& Raj, 2006) who have studied relationship marketing in $\mathrm{HEi}$, have created different models of relationship marketing which highlighted the existence of various factors that influence the development of relationship marketing in $\mathrm{HEi}$.

Hennig-Thurau et al. (2001) have developed a model combining the growing body of knowledge on relationship marketing in the context of educational services. The research was conducted on a sample of 1162 former students from six universities in Germany. Their model named "relationship qualitybased student loyalty (RQSL)" indicated that several dimensions of relationship quality determined student loyalty. The main results of their study 
Šereš L. et al.: Analysis of the Relationship Between the Quality of Academic Service..

suggested that the quality of teaching and students' emotional commitment are crucial for student loyalty.

Jurkowitsch et al. (2006) investigated relationship marketing in terms of finding the factors that have a decisive impact on the student and alumni satisfaction and their impact on university promotion. The authors proposed a student satisfaction model on the sample of students in Austria. The obtained results indicated that teaching services, culture and environment, relationships and university marketing affect the development of relations, while student personality and general economic climate do not have a direct impact on them.

Wong \& Wong (2011) have dealt with similar topics, so they explored the applicability of relationship marketing concepts within the self-financed tertiary education institutions in Hong Kong. Relying on the well-established relationship marketing concepts, authors presented a conceptual model which should investigate the causal relationship between commitment and student loyalty and the key determinants of relationship commitment. According to this model, only relationship commitment has a direct impact on student loyalty.

Sultan and Wong (2013) pointed out the antecedents and consequences of service quality. They claimed that students were experiencing service quality as a set of performance attributes necessary for the functioning of academic, administrative and support activities in HEls, while the service quality impact satisfaction and trust.

According to previously conducted research (Ackerman \& Schibrowsky, 2007; Kim \& Sax, 2009) there is a great importance of establishing stronger relationships between students and the student counsellors, teachers and administrative staff by implementing the better academic, administrative and extracurricular activities.

Further, Seifert and Burrow (2013) were exploring student affairs and service staff member perceptions about whether expanding service programs might have an impact on student success. The results of this study suggest that expansion of services providing by the student affairs professional rarely leads to a growth in the number of graduates.

\subsection{Behavioural intention of students}

There are several benefits of loyal students, with both short- and long-term impact on $\mathrm{HEi}$. Along with their positive effect on the process of teaching, they are more likely to recommend particular $\mathrm{HEi}$ and to continue studying at a higher level at the same university (Marzo-Navarro, Pedraja-Iglesias, \& Rivera-Torres, 2005b, 2005a; Thomas, 2011). Many previous studies highlighted the main benefits of loyal students: spreading positive "word-ofmouth" and their activity within the alumni organisation (Jaroslav Dado et al., 
Šereš L. et al.: Analysis of the Relationship Between the Quality of Academic Service..

2012; Hennig-Thurau et al., 2001). According to abovementioned, it can be concluded that their impacts should be linked not only to the period in which students have an active status at the university, but also their active role after graduation. Accordingly, Hennig-Thurau et al. (2001) indicated that student loyalty represents the multiphase concept that stretches from enrolment until their retirement and possibly further.

According to Dado et al. (2012) cognitive loyalty is based on direct experience or indirect knowledge of the performance superiority of a particular organisation (or brand) in comparison to another. Further, affective loyalty is a deeper level of commitment in comparison to the previous level, which is based on a specific brand preference based on many pleasures caused by the purchase. The conative phase of loyalty is also called phase of behavioural intentions that leads to motivation to re-purchase the product or service, while on the stage of action loyalty previous motivation turns into a willingness to act. The authors of this paper observe student loyalty in their conative phase, taking into account that students are not at the action stage of loyalty considering that they did not graduate.

According to the previously conducted research (Jaraslav Dado, Petrovicova, Riznic, \& Rajic, 2013; Jaroslav Dado et al., 2012; Woodside, Frey, \& Daly, 1989) service quality is directly related to the behavioural intentions. According to Dado et al. (2013), university administrators have a great impact on students motivation to recommend the institution to prospective students. Also, effective complaint management plays an essential role in creating loyal students. In that manner, Fontaine (2004) quotes the so-called paradox of successfully resolved complaints by Kotler according to which "rapid response to complaints of students, even if the answer to the same is not in favour of the student, can produce greater loyalty to the complainer than for students who are satisfied or did not complain at all".

\section{Research methods}

\subsection{Participants and data collection procedures}

Research participants are undergraduate students enrolled in the 4-year program at the University of Novi Sad. The total population covered by the survey includes approximately 44,000 students enrolled in the school year 2015/2016, while the sample for the study included 529 respondents who belong to the faculties of various scientific fields within the university. External atypical points were eliminated from the model by preliminary analysis of the assumptions of normality of distribution, reducing the number of respondents to 517. Invitation messages for participation in the online survey were sent via Facebook groups and also by sending the emails to over 2,000 universities students who belong to the population of this study. In addition to the content 
Šereš L. et al.: Analysis of the Relationship Between the Quality of Academic Service..

of the message (in a group and an email) that explains the purpose of the study, respondents received the URL where they could find an online form for answering. The process of gathering the data lasted two months and was completed at the end of February 2016. Among the participants, $15.5 \%$ of respondents belong to the field of mathematics and natural sciences, $27.6 \%$ of respondents belong to the technical field, $6.6 \%$ of the respondents belong to the technological field, and $50.3 \%$ of respondents belong to the social humanistic scientific field.

\subsection{Measures}

Empirical data was collected by using an importance-performance questionnaire. The questionnaire was based on the importance-performance analysis (IPA). Importance scale of the IPA is related to the importance of some services for customers, while the performance scale of the IPA is related to customer's satisfaction with provided services (Kitcharoen, 2004; Martilla \& James, 1977; Mourkani \& Shohoodi, 2013; O’Neill \& Palmer, 2004). In this study, the IPA questionnaire contains four groups of questions which are used to examine the service quality and relations of academic (professors and teaching assistants), administrative staff and faculty management according to students. Firstly, importance of certain services was investigated on a scale from 1 (not important) to 5 (very important) for each group of questions. Then, based on the students' opinion, the same services are evaluated regarding students' satisfaction with provided services, on a scale from 1 (very dissatisfied) to 5 (very satisfied).

The questionnaire consists of 29 questions. Out of the total number of questions, 20 of them are directly related to the services (an importanceperformance group of questions), four of them refer to $\mathrm{BI}$, and five of them were socio-demographic characteristics. Due to limitations on the availability of studies dealing with the issues described above, a group of 24 questions are the items which are adjusted from the previously conducted studies (de Jager \& Gbadamosi, 2010; Faganel, 2010; Kitcharoen, 2004; Levitz, Noel, \& Richter, 2002; Micari \& Pazos, 2012; Noel-Levitz, 2014; Sembiring, 2015; Sultan \& Wong, 2010). The questions about $\mathrm{BI}$ are in the form of statements which were confirmed in the previously conducted research (Bloemer, de Ruyter, \& Wetzels, 1999; Jaroslav Dado et al., 2012; Endres et al., 2009; Hennig-Thurau et al., 2001).

\subsection{Data analysis}

Data analysis was performed using statistical software for processing and analysis - SPSS (Statistical Package for the Social Sciences - SPSS v20). Hierarchical multiple regression analysis (HMRA) was conducted for measuring the statistically significant relationship between independent 
Šereš L. et al.: Analysis of the Relationship Between the Quality of Academic Service..

variables and $\mathrm{BI}$ of students as the dependent variable.

\section{Results}

Among the respondents $(\mathrm{N}=517), 24.5 \%$ are male and $75.5 \%$ are female students. According to the method of financing, $66.9 \%$ of respondents are studying at the expense of the state, while $33.1 \%$ of students self-financed their studies. Further, $25.3 \%$ are first-year students, $26.5 \%$ of students are on the second year, $21.2 \%$ of students are in the third year, and $27 \%$ of them are in the fourth year of their study. The majority of respondents are between 21 and 23 years of age (46.1\%), and according to type of secondary school they have finished, those who have completed secondary vocational education are in majority (55.1\%).

Table 1. PCA loadings, mean, SD and Cronbach's alpha values for each component

\begin{tabular}{|c|c|c|c|c|}
\hline Items and components & Mean & SD & VE & $\mathbf{C A}$ \\
\hline \multicolumn{5}{|l|}{ (ASAS) Approachability and support of academic staff ${ }^{\text {PCA }}$} \\
\hline Teaching assistants regularly hold consultations & -0.735 & 1.068 & \multirow{10}{*}{\multicolumn{2}{|c|}{$49.5 \% .927$}} \\
\hline $\begin{array}{l}\text { Teaching assistants are approachable through the available } \\
\text { channels of communication }\end{array}$ & -0.799 & 0.999 & & \\
\hline $\begin{array}{l}\text { Teaching assistants monitor the progress of students on the course } \\
\text { and inform them about it }\end{array}$ & -0.946 & 1.250 & & \\
\hline Teaching assistants are kind to the students & -0.913 & 1.156 & & \\
\hline $\begin{array}{l}\text { Teaching assistants are competent and provide a high quality of } \\
\text { teaching }\end{array}$ & -0.934 & 1.071 & & \\
\hline Professors regularly hold consultations & -0.897 & 1.171 & & \\
\hline $\begin{array}{l}\text { Professors monitor the progress of students on the course and } \\
\text { inform them about it }\end{array}$ & -1.222 & 1.304 & & \\
\hline $\begin{array}{l}\text { Professors are approachable through the available channels of } \\
\text { communication }\end{array}$ & -1.128 & 1.117 & & \\
\hline Professors are competent and provide a high quality of teaching & -1.083 & 1.043 & & \\
\hline \multicolumn{3}{|l|}{ (SOMF) Support of management of faculty ${ }^{\mathrm{PCA}}$} & & \\
\hline Faculty management provides financial support & -2.017 & 1.454 & \multirow{7}{*}{\multicolumn{2}{|c|}{$11.3 \% .933$}} \\
\hline quick resolution of complaints & -1.646 & 1.330 & & \\
\hline Faculty management is characterized by expediency & -1.818 & 1.419 & & \\
\hline $\begin{array}{l}\text { Faculty management provides scholarships and awards for the } \\
\text { achieved results }\end{array}$ & -1.691 & 1.311 & & \\
\hline Faculty management expresses concern for students & -1.805 & 1.423 & & \\
\hline Faculty management is approachable to students & -1.420 & 1.347 & & \\
\hline $\begin{array}{l}\text { Faculty management ensures data security } \\
\text { (SASC) Student affair staff cooperation }{ }^{\text {PCA }}\end{array}$ & -1.164 & 1.208 & & \\
\hline Student affairs staff is willing to cooperate & -0.820 & 1.408 & \multirow{3}{*}{$8.8 \%$} & \multirow{3}{*}{.951} \\
\hline Student affairs staff approachable to students & -0.917 & 1.422 & & \\
\hline $\begin{array}{l}\text { Student affairs staff is friendly towards students } \\
\text { I) Behavioural intention }\end{array}$ & -0.896 & 1.476 & & \\
\hline Absence of intention to leave the university & 4.40 & .969 & \multirow{4}{*}{$60 \%$} & \\
\hline Willingness to recommend the faculty & 3.40 & 1.384 & & \\
\hline Willingness to continue their studies at the same university & 3.53 & 1.332 & & 76 \\
\hline I would choose the same faculty & 3.56 & 1.400 & & \\
\hline
\end{tabular}

Note: SD - Standard Deviation; CA - Cronbach's Alpha coefficient; VE - variance explained; PCA - Principal Component Analysis 
Šereš L. et al.: Analysis of the Relationship Between the Quality of Academic Service..

The results of Pearson correlations are shown in Table 2. Due to the high linear correlation $(r>=0.7)$, ten independent variables had to be omitted from the process of regression analysis.

Table 2. Mean, Standard Deviation and Pearson Correlations

\begin{tabular}{|c|c|c|c|c|c|c|c|c|c|c|c|c|c|c|}
\hline & Mean & SD & 1 & 2 & 3 & 4 & 5 & 6 & 7 & 8 & 9 & 10 & 12 & 12 \\
\hline 1 & .000 & 1.000 & 1.000 & & & & & & & & & & & \\
\hline 2 & 2.487 & 1.135 & $-351^{\star *}$ & 1.000 & & & & & & & & & & \\
\hline 3 & -1.128 & 1.117 & $461^{* *}$ & $-.244^{\star *}$ & 1.000 & & & & & & & & & \\
\hline 4 & -1.083 & 1.043 & $.492^{\star *}$ & $-.216^{* *}$ & $.586^{\star *}$ & 1.000 & & & & & & & & \\
\hline 5 & -1.267 & 1.213 & $.439^{\star *}$ & $-.194^{* *}$ & $.601^{* *}$ & $.552^{\star *}$ & 1.000 & & & & & & & \\
\hline 6 & -0.897 & 1.171 & $.372^{\star *}$ & $-.229^{* *}$ & $.592^{\star \star}$ & $.481^{\star *}$ & $.530^{\star *}$ & 1.000 & & & & & & \\
\hline 7 & -1.222 & 1.304 & $.332^{* *}$ & $-.250^{* *}$ & $.517^{* *}$ & $.474^{* *}$ & $.531^{* *}$ & $.624^{\star *}$ & 1.000 & & & & & \\
\hline 8 & -0.934 & 1.071 & $.411^{\star \star}$ & $-.218^{\star *}$ & $.493^{* *}$ & $.649^{\star \star}$ & $.440^{* *}$ & $.489^{* *}$ & $.441^{\star \star}$ & 1.000 & & & & \\
\hline $\begin{array}{c}9 \\
10\end{array}$ & $\begin{array}{l}-0.946 \\
-1.164\end{array}$ & $\begin{array}{l}1.250 \\
1.208\end{array}$ & $\begin{array}{l}.318^{\star *} \\
.348^{\star *}\end{array}$ & $\begin{array}{l}-.244^{\star *} \\
-.231^{\star *}\end{array}$ & $\begin{array}{l}.453^{\star \star} \\
.402^{\star *}\end{array}$ & $\begin{array}{l}.451^{\star *} \\
.415^{\star *}\end{array}$ & $\begin{array}{l}.471^{\star *} \\
.402^{\star *}\end{array}$ & $\begin{array}{l}.561^{\star \star} \\
.398^{\star \star}\end{array}$ & $\begin{array}{l}.654^{\star *} \\
.356^{* *}\end{array}$ & $\begin{array}{l}.621^{\star *} \\
.389^{\star *}\end{array}$ & $\begin{array}{l}1.000 \\
.400^{* *}\end{array}$ & 1.000 & & \\
\hline 11 & -1.646 & 1.330 & $.462^{\star \star}$ & $-.311^{* *}$ & $.459^{\star *}$ & $.446^{\star \star}$ & $.472^{\star \star}$ & $.410^{* *}$ & $.366^{\star \star}$ & $.418^{\star *}$ & $.328^{\star \star}$ & $.635^{\star \star}$ & 1.000 & \\
\hline 12 & -2.017 & 1.454 & $420^{\star *}$ & $-.237^{\star *}$ & $.370^{\star *}$ & $.366^{\star \star}$ & $.439^{\star \star}$ & $.327^{\star *}$ & $.358^{\star *}$ & $.357^{\star *}$ & $.356^{\star *}$ & $.574^{\star *}$ & $.699^{* \star}$ & 1.000 \\
\hline
\end{tabular}

Note: ${ }^{* * *}$ - sig.< 0.001; ${ }^{* *}-\operatorname{sig}<.005 ;{ }^{*}-\operatorname{sig}<.05 ; 1$. BI; 2. Year of study; 3. Professors are approachable through the various channels of communication; 4. Professors are competent and provide a high quality of teaching; 5. Professors are kind; 6. Professors regularly hold consultations; 7. Professors monitor the progress of students and inform them about it; 8 . Teaching assistants are competent and provide a high quality of teaching; 9. Teaching assistants monitor the progress of students and inform them about it; 10. Faculty management ensures data security; 11. Faculty management provides a quick resolution of complaints; 12. Faculty management provides financial aid.

The relationships between variables are shown in Table 3. HRME analysis was started by entering the variable "Year of study" as a control variable. In the second step, variables related to the component ASAS were entered. After removing the influence of variables entered in the first and the second step, the third block of variables belongs to the component named SOFM. The component SASC has no significant correlation with the BI of students, and the variables of this component were excluded from the further analysis. Results of Durbin-Watson test $(\mathrm{DW}=1.925$ ) has shown that the model has no significant autocorrelation. The values of Tolerance and VIF for each variable of the model indicated that there is no presence of multicollinearity.

In the same table, the test of normality of distribution of residuals did not show the presence of anomalies, which are confirmed by tests of KolmogorovSmirnov (statistic=.038; $p=0.73$ ) and Shapiro-Wilk (statistic=.995; $p=0.125$ ). The additional analysis did not confirm the presence of homoscedasticity of residuals.

During the examination of the results of HMRA presented in Table 3, it can be seen that control variable "Year of Study" explained $12.4 \%$ of the variance of the first model (model 1). 
Šereš L. et al.: Analysis of the Relationship Between the Quality of Academic Service..

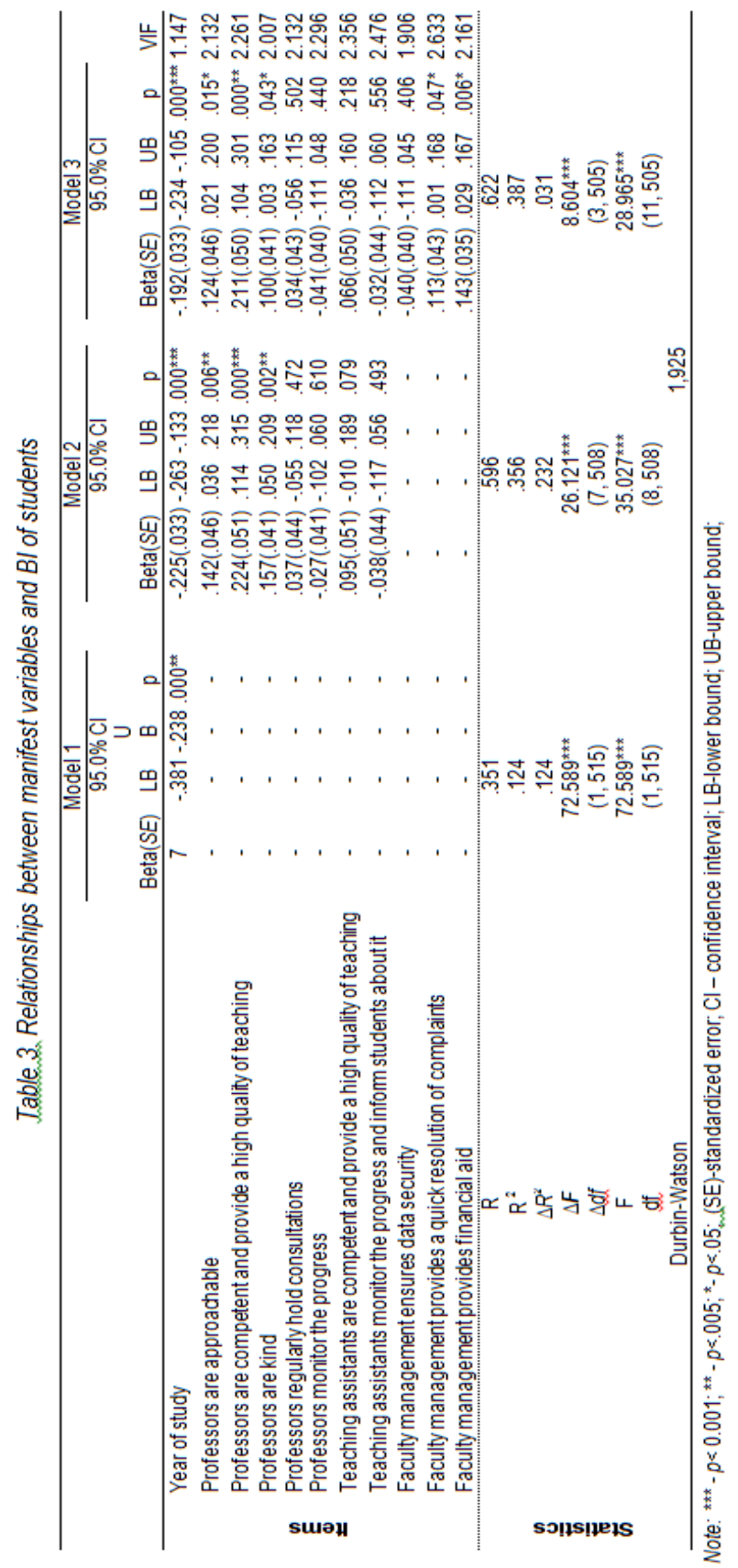


Šereš L. et al.: Analysis of the Relationship Between the Quality of Academic Service..

Further, the second model was created by inputting the manifest variables belonging to the component named "Approachability and support of academic staff", which explained an additional $35.6 \%$ of the variance of the second model. The third step was performed by inputting the variables from the component named "Support of faculty management". After that, model as a whole explains $38.7 \%$ of the variance of students $\mathrm{BI}$ with the level of significance $[\mathrm{F}(11,505)=$ $28,965 ; p<0.001]$. Multiple correlation coefficient $(\mathrm{R})$ of the model as a whole was 0.622 which indicates a high intensity of the connection between the set of predictors and criterion variable.

By controlling for the impact of "years of study", seven independent variables were entered in the second block explaining an additional $23.2 \%$ of the variance of students $\mathrm{BI}$ (model 2). Thus, the coefficient of determination of the second model changed by $\Delta R^{2}=0.232$ with a significance level $[\Delta F(7,508)=26.121$, $p$ $<0.001]$. The third model, besides variables entered during the third step, contains all the variables entered in the first and the second step. However, by controlling for the impact of variables entered in the second block, the variables related to the Support of faculty management explained additional $3.1 \%$ of the variance of $\mathrm{BI}$ of students, while the coefficient of determination was changed by $\Delta \mathrm{R}^{2}=0.31$ with a level of significance $[\Delta \mathrm{F}(3,505)=8.604, p<0.001]$.

According to the final model, hierarchical multiple regression analysis revealed that six of the eleven variables had a statistically significant relation with students $\mathrm{BI}$. The regressor "Professors are competent and provide a high quality of teaching" has the highest beta coefficient $(\beta=.211, p<0.001)$ with a positive effect on the BI. Further, the control variable "years of study" has the second largest beta coefficient $(\beta=-.192, p<0.001)$ but with a negative significance, which causes the opposite direction of movement about the dependent variable. Also, the variable "Faculty management provides financial aid" represents a statistically significant regressor with the third largest beta coefficient (beta = $.143, p<0.05)$. The remaining three regressors proved to be statistically significant with a level of significance $p<0.01$, with a lower share of the variance about the regressors mentioned above ("Professors are approachable through various channels of communication" $(\beta=.124, p<015)$; "Professors regularly hold consultations" ( $\beta=.100, p<0.43)$ and the variable "Faculty management provides a quick resolution of complaints" $(\beta=.113, p<0.47))$. 
Šereš L. et al.: Analysis of the Relationship Between the Quality of Academic Service..

\section{Discussion}

Results obtained from this study clearly show that the competence of the professors had the strongest positive statistically significant impact on students' behavioural intentions. In addition to the professor's competence, their approachability and kindness had a positive influence on students' BI. Furthermore, providing financial aid and quick resolution of complaints by faculty management were significant predictors as well. Concerning the years of study, obtained results indicated that students with more experience express less willing to persist.

As it was mentioned, variable "Faculty management provide financial aid" has the third largest predictive power of student BI. Accordingly, it can be concluded that the results coincide with the results of the previously conducted research (Johnson et al., 2014; Oseguera et al., 2009) in which financial need expressed a direct and indirect effect on student persistence, and the financial concern affects the persistence of students regarding the intention to transfer to another HEl. Further, Bowles and Brindle (2017) indicated that financial aid is a significant factor in student retention, while according to Lechtchinskaia (2012) financial aid and financial donations present essential aspects of managing relationships with students.

Complaint management as a process of resolving complaints of dissatisfied students is very important if faculty management wants to nurture good relationships with students and to align provided services with their expectations. According to obtained results, quick resolution of complaints by faculty management was a significant predictor of $\mathrm{BI}$. It may be noted that the results obtained in a particular domain coincide with the results of the previously conducted research in which author (Sembiring, 2015) proves that there is an indirect influence of complaints management on persistence and retention of students, through their satisfaction.

\section{Implications}

This study contains several theoretical and practical implications. Firstly, the results provide a new dimension to current aspects of student intentions. In this regard, this study shall primarily be of interest of the professional and academic community that will give their critical assessment of the presented models and to 
Šereš L. et al.: Analysis of the Relationship Between the Quality of Academic Service..

provide any recommendations for their improvement. Secondly, the results can also serve to management policymakers of $\mathrm{HEI}$ to better understand and manage relationships with the students. Identification, measurement and evaluation of key performance indicators, permanent tracking of activities of each student would establish proper policy controls necessary to monitor students' BI. Besides directly measurable performance indicators, the information obtained by interviewing the students can be valuable feedback, both in analytical and in operational terms and used for improving the delivery of specific services.

\section{Limitation and directions for future research}

This study has two limitations. Firstly, only a limited number of independent variables were used in regression analysis. Recommended independent variables which could be used in future research would be related to the students' successful outcome or material status of the student, which could have an impact on the presented results. Secondly, considering that the survey sample included only students of the one state university, but not students from private HEls, it is difficult to generalise obtained results.

Future directions of research should be primarily focused on expanding this study in the aim of better understanding the student complaint management processes and identification of performance indicators that can be placed in the context of it, as well.

\section{Conclusion}

The main objectives of this paper were to identify components and items of service quality that may have an impact on the behavioural intention of students. Although it was focused on analysing the relationship between educational service quality and behavioural intention of students, the paper states an indirect connection of obtained results with particular aspects of financial assistance and student's complaint management. Results of this study might be very useful in defining the strategies related to the improvement of $\mathrm{HEI}$ service quality. Harmonisation of the provided service quality with student's expectations represents an important task for the HEl. Results presented in this paper provide some useful information needed for the optimal allocation of resources devoted to ensure educational services on the expected level. This research has confirmed 
Šereš L. et al.: Analysis of the Relationship Between the Quality of Academic Service..

that improving the quality of services provided by the management and staff of faculty, has positive effects on behavioural intentions of students. About this general statement, a special contribution to this subject is given by pointing to a different level of significance of individual service quality components and items as predictors of students' BI.

\section{References}

Ackerman, R., \& Schibrowsky, J. (2007). A Business Marketing Strategy Applied to Student Retention: A Higher Education Initiative. Journal of College Student Retention: Research, Theory and Practice, 9(3), 307-336. https://doi.org/10.2190/CS.9.3.d

Arnett, D. B., German, S. D., \& Hunt, S. D. (2003). Identity Salience Model of Success: Relationship Marketing The of Nonprofit Marketing. The Journal of Marketing, 67(2), 89-105.

Bloemer, J., de Ruyter, K., \& Wetzels, M. (1999). Linking perceived service quality and service loyalty: a multi-dimensiona perspective. European Journal of Marketing, 33(11/12), 1082-1106. https://doi.org/10.1108/03090569910292285

Bowles, T. V., \& Brindle, K. A. (2017). Identifying facilitating factors and barriers to improving student retention rates in tertiary teaching courses: a systematic review. Higher Education Research \& Development, O(0), 1-17. https://doi.org/10.1080/07294360.2016.1264927

Dado, J., Petrovicova, J., Cuzovic, S., \& Rajic, T. (2012). An empirical examination of the relationships between service quality, satisfaction and behavioral intentions in higher education setting. Serbian Journal of Management, 7(2), 203-218. https://doi.org/10.5937/sjm.v7i2.1245

Dado, J., Petrovicova, J. T., Riznic, D., \& Rajic, T. (2013). Linking Service Quality and Satisfaction to Behavioural Intentions in Higher Education Setting. Ekonomický Časopis, 61(6), 578-596.

Danjuma, I., \& Rasli, A. (2012). Service Quality , Satisfaction And Attachment In Higher Education Institutions: A Theory Of Planned Behaviour Perspective. International Journal of Academic Research, 4(2), 96-103.

de Jager, J., \& Gbadamosi, G. (2010). Specific remedy for specific problem: Measuring service quality in South African higher education. Higher Education, 60(3), 251-267. https://doi.org/10.1007/s10734-009-9298-6

Endres, M. L., Chowdhury, S., Frye, C., \& Hurtubis, C. A. (2009). The Multifaceted Nature of Online MBA Student Satisfaction and Impacts on Behavioral Intentions. Journal of Education for Business, 84(5), 304-312. https://doi.org/10.3200/JOEB.84.5.304-312

Faganel, A. (2010). Quality perception gap inside the higher education institution. International Journal of Academic Research, 2(1), 213-215.

Helen, W., \& Ho, W. (2011). Building Relationship between Education Institutions and Students: Student Loyalty in Self-Financed Tertiary Education. IBIMA Business

Industrija, Vol.47, No.2, 2019 
Šereš L. et al.: Analysis of the Relationship Between the Quality of Academic Service..

Review Journal, 2011, 1-22. https://doi.org/10.5171/2011.913652

Hennig-Thurau, T., Langer, M. F., \& Hansen, U. (2001). Modeling and managing student loyalty: an approach based on the concept of relationship quality. Journal of Service Research, 3(4), 331-344. https://doi.org/10.1177/109467050134006

Johnson, D. R., Wasserman, T. H., Yildirim, N., \& Yonai, B. A. (2014). Examining the Effects of Stress and Campus Climate on the Persistence of Students of Color and White Students: An Application of Bean and Eaton's Psychological Model of Retention. Research in Higher Education, 55(1), 75-100. https://doi.org/10.1007/s11162-013-9304-9

Jurkowitsch, S., Vignali, C., \& Kaufmann, H.-R. (2006). A student satisfaction model for Austrian higher education providers considering aspects of marketing communications. Innovative Marketing, 2(3), 9-23.

Kim, Y. K., \& Sax, L. J. (2009). Student-faculty interaction in research universities: Differences by student gender, race, social class, and first-generation status. Research in Higher Education, 50(5), 437-459. https://doi.org/10.1007/s11162-0099127-x

Kitcharoen, K. (2004). The importance-performance analysis of service quality in administrative departments of private universities in Thailand. ABAC Journal, 24(3), $20-46$.

Lechtchinskaia, L., Friedrich, I., \& Breitner, M. H. (2012). Requirements Analysis for a Student Relationship Management System-Results from an Empirical Study in Ivy League Universities. 2012 45th Hawaii International Conference on System Sciences, 5132-5141. https://doi.org/10.1109/HICSS.2012.502

Letcher, D., \& Neves, J. (2010). Determinants of undergraduate business student satisfaction. Research in Higher Education Journal, 6(1), 1-26.

Levitz, R. S., Noel, L., \& Richter, B. J. (2002). Strategic Moves for Retention Success. New Directions for Higher Education, 1999(108), 31-49. https://doi.org/10.1002/he.10803

Liaw, S. S. (2008). Investigating students' perceived satisfaction, behavioral intention, and effectiveness of e-learning: A case study of the Blackboard system. Computers and Education, 51(2), 864-873. https://doi.org/10.1016/j.compedu.2007.09.005

Martilla, J., \& James, J. (1977). Importance-performance analysis. Journal of Marketing.

Marzo-Navarro, M., Pedraja-Iglesias, M., \& Rivera-Torres, M. P. (2005a). A new management element for universities: satisfaction with the offered courses. International Journal of Educational Management, 19(6), 505-526.

Marzo-Navarro, M., Pedraja-Iglesias, M., \& Rivera-Torres, M. P. (2005b). Measuring customer satisfaction in summer courses. Quality Assurance in Education, 13(1), 53-65.

Micari, M., \& Pazos, P. (2012). Connecting to the Professor: Impact of the Student-Faculty Relationship in a Highly Challenging Course. College Teaching, 60(2001), 41-47. https://doi.org/10.1080/87567555.2011.627576

Mourkani, G., \& Shohoodi, M. (2013). Quality Assurance in Higher Education: Combining Internal Evaluation and Importance-Performance Analysis Models. Middle East Journal of Scientific Research, 15(5), 643-651. https://doi.org/10.5829/idosi.mejsr.2013.15.5.217 
Šereš L. et al.: Analysis of the Relationship Between the Quality of Academic Service..

Noel-Levitz. (2014). National Student Satisfaction and Priorities Report (Vol. 16).

O'Neill, M., \& Palmer, A. (2004). Importance-performance analysis: a useful tool for directing continuous quality improvement in higher education. Quality Assurance in Education, 12(1), 39-52.

Oldfield, B., \& Baron, S. (2000). Student perceptions of service quality in a UK university business and management faculty. Quality Assurance in Education, 8(2), 85-95.

Oseguera, L., \& Rhee, B. S. (2009). The Influence of Institutional Retention Climates on Student Persistence to Degree Completion: A Multilevel Approach. Research in Higher Education, 50(6), 546-569.

Park, S. Y. (2009). An Analysis of the Technology Acceptance Model in Understanding University Students' Behavioral Intention to Use e-Learning. Educational Technology \& Society, 12(3), 150-162. https://doi.org/10.1007/s00340-009-3513-0

Rashid, T., \& Raj, R. R. (2006). Customer Satisfaction: Relationship Marketing In Higher Education E-Learning. Innovative Marketing, 2(3), 24-34.

Rodić Lukić, V. (2015). Kvalitet usluge u funkciji satisfakcije $i$ namera korisnika u ostvarivanju marketing performansi visokoobrazovnih institucija na Zapadnom Balkanu, Doktorska dizertacija. Univerzitet u Novom Sadu.

Rodić Lukić, V., \& Lukić, N. (2018). Assessment of student satisfaction model: evidence of Western Balkans. Total Quality Management \& Business Excellence, $0(0), 1-13$. https://doi.org/10.1080/14783363.2018.1489227

Seifert, T. a, \& Burrow, J. (2013). Perceptions of Student Affairs and Services Practitioners in Ontario's Post-Secondary Institutions: An Examination of Colleges and Universities. Canadian Journal of Higher Education, 43(2), 132-148.

Sembiring, M. G. (2015). Validating student satisfaction related to persistence, academic performance, retention and career advancement within ODL perspectives. Open Praxis, 7(4), 325-337. https://doi.org/10.5944/openpraxis.7.4.249

Sultan, P., \& Wong, H. (2010). Performance-based service quality model: an empirical study on Japanese universities. Quality Assurance in Education, 18(2), 126-143. https://doi.org/10.1108/09684881011035349

Sultan, P., \& Yin Wong, H. (2013). Antecedents and consequences of service quality in a higher education context. Quality Assurance in Education, 21(1), 70-95. https://doi.org/10.1108/09684881311293070

Sumaedi, S., Bakti, I., \& Metasari, N. (2011). The effect of students' perceived service quality and perceived price on student satisfaction. Management Science and Engineering, 5(1), 88-97.

Thomas, S. (2011). What drives student loyalty in universities: An empirical model from India. International Business Research, 4(2), 183-192. https://doi.org/10.5539/ibr.v4n2p183

Veljković, S. (2009). Marketing usluga. Beograd: Centar za izdavačku delatnost Ekonomskog fakulteta u Beogradu.

Voss, R., Gruber, T., \& Reppel, A. (2010). Which classroom service encounters make students happy or unhappy?: Insights from an online CIT study. International Journal of Educational Management, 24(7), 615-636.

Watjatrakul, B. (2014). Factors affecting students' intentions to study at universities 
Šereš L. et al.: Analysis of the Relationship Between the Quality of Academic Service..

adopting the "student-as-customer" concept. International Journal of Educational Management, 28(6), 676-693. https://doi.org/10.1108/IJEM-09-2013-0135

Wong, H., \& Wong, K. H. (2011). Building relationship between education institutions and students: student loyalty in self-financed tertiary education. IBIMA Business Review Journal, 2011, 1-22.

Woodside, A. G., Frey, L. L., \& Daly, R. T. (1989). Linking Service Quality, Customer Satisfaction, And Behavioral intention. Journal of Health Care Marketing, 9(4), 5-17. 